\title{
Effects of Replacing Maize with Graded Levels of Cassava Tuber Meal, Brewer's Dried Grain and Palm Oil Mixture on the Serum Biochemistry and Carcass Characteristics of Broiler Chickens
}

\author{
U. Okpanachi, A. A. Musa, A. T. Adewoye and O. C. Adejoh \\ Department of Animal Production, Kogi State University, Anyigba, Kogi State, Nigeria
}

\begin{abstract}
An experiment was conducted to determine the value of a mixture of sun-dried cassava tuber meal $(C)$, brewers' dried grains $(B)$, and palm oil $(P)(C B P$-mix) based diets with a view to determine its optimal dietary maize replacement levels in broiler starter and finisher diets, its effects on serum biochemistry and carcass characteristics of broilers. Sun-dried Cassava tuber meal (C), Brewers' dried grains (B) and Palm oil $(P)$ were mixed in ratio 60:35:5 respectively. A total of 120 day old broiler chicks were allotted to 4 dietary treatments, in a completely randomised design, containing 0\%, 15\%, 30\% and 45\% CBP-mix replacement levels for maize. At the end of the experiment data collected were subjected to one way analysis of variance using SPSS package version 17. All the carcass parameters measured except for drumstick were significant $(P<$ $0.05)$. The birds on control performed significantly better $(P<0.05)$ than those on CBP-mix diets in terms of live, carcass and thigh weights. Diet 3 (30\% CBP-mix) however had the highest dressing percentage, breast muscle and liver. All the serum biochemical parameter showed significant difference $(P<0.05)$. The highest value of Albumin and total protein recorded for birds in diet 4 (45\% CBP-mix) suggests high quality of protein while the highest creatinine for birds on diet 1 suggests muscular wastage. Conclusively, diet 3 (30\% CBP-mix) was recommended considering dressing percentage, breast and liver weights. Incorporation of these levels of CBPmix in the diets of broilers does not have any negative effect on the carcass characteristic and serum biochemical profile of the birds.

Key words: CBP-mix, Cassava Tuber Meal, Brewer's Dried Grain, Palm Oil, Broiler, Carcass
\end{abstract}

\section{Introduction}

Feeding has always posed a problem to the livestock and poultry industry in the tropics. This consequently leads to the high cost of production of highly needed animal protein (Tona et al., 2010). Maize for example is a major feedstuff and it is in high demand for consumption by both humans and livestock. The competition and inadequate supply have invariably led to their constant increasing market price. The high cost of maize is a major contributor to the increasing cost of poultry production. This has made many poultry keepers to reduce their flock or completely shift to other business with lesser financial involvement (Esonu, 2000).

The current trend in poultry industry is on alternative feedstuff; mainly those that can either directly replace maize or can be incorporated at certain levels in the diet to achieve a comparable worth (Chukwuka et al., 2010; Ironkwe and Bamgbose, 2012; Udedibie et al., 2012; Okpanachi et al., 2013). One of such alternative feedstuff is a mixture of sun-dried cassava tuber meal (C), brewers' dried grains (B), and palm oil (P) (CBP-mix).

Eyenihi et al. (2008) described the sun - dried cassava tuber meal as a good source of carbohydrate, and brewer dried grains to be rich in protein, while he mentioned palm oil as a stabilizer with high energy source.

Substantial efforts have been made in the past decade to evaluate the effects of CBP-mix on performance of birds (udedibie et al., 2008; chukwuka et al., 2010; udedibie et al., 2012; Okpanachi et al., 2013). However, there is dearth of information on the effects of CBP-mix on serum biochemistry and carcass characteristics of broiler chickens.

Carcass studies gives an understanding of the general performance via weight gain, and other parameters but improved productivity of any class of livestock based on any feedstuff necessitates an understanding of its physiology including the biochemical assay of the animal. Therefore, physiological studies are undertaken to establish a diagnostic baseline of the blood characteristics for the routine management practices of the farm animal which in turn is employed by animal scientists (Okorie, 2006). Thus biochemical constituents reflect the physiological responsiveness of the animal to its external and internal environment. The study was therefore aimed at evaluating the serum biochemistry and carcass characteristics of broiler chickens fed graded levels of CBP-mix as a substitute for maize. 


\subsection{Experimental Location and Diet}

\section{Materials and Methods}

This research work was conducted at the Poultry Unit of the Teaching and Research Farm of the Department of Animal Production, Kogi State University, Anyigba, Kogi State. Anyigba lies on latitude $7^{0} 15$ and $7^{0} 29 \mathrm{~N}$ of the equator and longitudes $7^{0} 11$ and $7^{0} 32 \mathrm{E}$ of the Greenwich meridian (Ifatimehin et al., 2006).

Sun dried cassava tuber meal, brewers dried grains and palm oil were weighed out at a ratio of 60:35:5 representatively and thoroughly mixed to produce CBP-mix. Four iso-nitrogenous diets were formulated such that diet 1 (control) contained maize as the chief energy source while CBP-mix was used to replace maize at $33.33,66.67$ and $100.00 \%$ in diets 2,3 and 4 respectively as shown in Table 1.

Table 1: Composition of the Experimental Diets

\begin{tabular}{|c|c|c|c|c|c|c|c|c|}
\hline & \multicolumn{4}{|c|}{ Starter phase } & \multicolumn{4}{|c|}{ Finisher phase } \\
\hline & \multicolumn{8}{|c|}{ Graded levels of CBP-mix } \\
\hline Ingredients & $0 \%$ & $15 \%$ & $30 \%$ & $45 \%$ & $0 \%$ & $15 \%$ & $30 \%$ & $45 \%$ \\
\hline Maize & 45.00 & 30.00 & 15.00 & 0.00 & 45.00 & 30.00 & 15.00 & 0.00 \\
\hline CBP-mix & 0.00 & 15.00 & 30.00 & 45.00 & 0.00 & 15.00 & 30.00 & 45.00 \\
\hline GNC & 36.80 & 37.28 & 36.41 & 36.38 & 27.68 & 28.02 & 28.02 & 27.11 \\
\hline Maize offal & 11.45 & 10.97 & 11.84 & 11.87 & 21.07 & 20.73 & 20.73 & 21.64 \\
\hline Fish meal & 2.50 & 2.50 & 2.50 & 2.50 & 2.50 & 2.50 & 2.50 & 2.50 \\
\hline Bone meal & 3.50 & 3.50 & 3.50 & 3.50 & 3.00 & 3.00 & 3.00 & 3.00 \\
\hline Methionine & 0.25 & 0.25 & 0.25 & 0.25 & 0.25 & 0.25 & 0.25 & 0.25 \\
\hline Salt & 0.25 & 0.25 & 0.25 & 0.25 & 0.25 & 0.25 & 0.25 & 0.25 \\
\hline Premix * & 0.25 & 0.25 & 0.25 & 0.25 & 0.25 & 0.25 & 0.25 & 0.25 \\
\hline \multicolumn{9}{|c|}{ Calculated analysis } \\
\hline Crude protein & 23.00 & 23.23 & 23.00 & 23.00 & 20.00 & 20.00 & 20.00 & 20.00 \\
\hline $\begin{array}{l}\text { Metabolisable Energy } \\
(\mathrm{Kcal} / \mathrm{kg})\end{array}$ & 2787.87 & 2688.42 & 2610.35 & 2521.18 & 2824.68 & 2734.58 & 2645.33 & 2558.35 \\
\hline Calcium & 1.32 & 1.35 & 1.39 & 1.42 & 1.33 & 1.39 & 1.39 & 1.42 \\
\hline Phosphorus & 1.22 & 1.05 & 1.03 & 1.01 & 1.02 & 0.98 & 0.98 & 0.96 \\
\hline
\end{tabular}

ME: Metabolisable energy; GNC: Groundnut cake; CBP-mix: Cassava tuber meal; Brewers dried grain and Palm oil mixture; Premix* Bio-mix supplied per tonne: Vit A 5,000000 I.U., Vit $\mathrm{D}_{3} 1,000000$ I.U., Vit E 20,000mg, Vit $\mathrm{K}_{3} 1000 \mathrm{mg}$; Vit B 1 , $1200 \mathrm{mg}$,Vit $\mathrm{B}_{2}$ 2400mg, Vit $\mathrm{B}_{6} 2400 \mathrm{mg}$, Niacin 16,000mg; Calcium pantothenate 4,000mg, Biotin 32mg; Vit B 12 10mg; Folic acid 400mg; Chlorine chloride 120,000mg: Manganese 40,000mg; Iron 20,000mg; Zinc 18,000mg; Copper 800mg; Cobalt 100mg, Iodine 620mg, Selenium 40mg.

\subsection{Experimental Animals and Management}

120 day old unsexed broiler chicks (Anak strain) were randomly divided into 4 treatments of 30 birds each. Each treatment was replicated 3 times with 10 birds per replicate. The experiment lasted 9 weeks i.e. 4 and 5 weeks for starter and finisher phases respectively. The birds were reared in deep litter system. Fresh water and treatment diets were supplied ad libitum throughout the period of the experiment. Routine management practices including vaccination and drug administration when necessary were duly observed.

\subsection{Data Collection}

At the beginning of the experiment, the birds were weighed and subsequently on weekly basis. The initial live weight was subtracted from the final live weight to determine the weight gained by the animals.

\subsubsection{Carcass Analysis}

On conclusion of the feeding trial, the birds were fasted overnight, 3 birds per replicate were selected and weighed the following morning prior to slaughtering to obtain their live weights. The birds were slaughtered by severing the jugular vein. The carcasses were allowed to bleed freely for 5 minutes, defeathered using warm water and then re-weighed to obtain plucked carcass weight. They were then decapitated, eviscerated and weighed to obtain the dressed weights. The carcass was subsequently dissected into various primal cuts (breast, back, drumstick, thigh, wing and neck) according to Kleczek et al. (2007), giblets (gizzard, liver and heart) and their weights were also taken. Dressing percentage was expressed as dressed carcass weight over live weight, multiplied by 100 while the carcass cuts were expressed in grams per kilogram. An electronic top loading (Citizen Electronic Balance, Goldair) scale with maximum weight of $3 \mathrm{~kg}$ (sensitive at $0.1 \mathrm{~g}$ ) was used to weigh the birds, the carcasses, the giblets and the various primal cuts. 


\subsubsection{Serum Biochemical Analysis}

At the $9^{\text {th }}$ week of the experiment, birds were fasted overnight so that the serum was cleared of excess fat and protein that could cloud results. 2 birds per replicate were randomly selected for blood collection. Blood was collected using a $2 \mathrm{ml}$ disposable sterile syringe and needle from wing vein into sterile test tubes without anticoagulant. All the samples were centrifuged to obtain serum which was stored at $-10^{\circ} \mathrm{c}$ until analysed. The serological (Albumin, Alkaline phosphatase, Creatinine, Globulin and Total protein) parameter were determined using the standard clinical chemistry procedure (Riesman and Frankel, 1957).

\subsection{Chemical and Statistical Analysis}

The proximate composition of CBP-mix and the experimental diets were determined using the methods outlined by AOAC (1995). Data collected were subjected to a one way analysis of variance using the SPSS version 17.0. Differences between means were separated using the Least Significant Difference in SPSS package.

\section{Results \\ 3.1 Carcass characteristics of broilers fed graded levels of CBP-mix}

Carcass characteristics of finished broilers fed graded levels of CBP-mix diets are as shown in Table 2. There were significant differences $(\mathrm{P}<0.05)$ for all the parameters except for the drumstick weight. Broilers fed diet $1(0 \%$ CBP-mix) were significantly $(\mathrm{P}<0.05)$ heavier than those finished on diets 2,3 and 4 containing 15 , 30 and $45 \%$ CBP-mix diets. The carcass weights also followed the same trend as live weight however; broilers fed 0 and 30\% CBP-mix diets had comparable $(\mathrm{P}>0.05)$ carcass weights. The dressing percentage of broilers fed 0 and 30\% CBP-mix diets were comparable but statistically $(\mathrm{P}<0.05)$ higher than those fed $45 \%$ CBP-mix diet. The neck weight of broilers fed 15 and 30\% CBP-mix diets were statistically similar but significantly $(\mathrm{P}<$ 0.05 ) higher than those fed $45 \%$ CBP-mix diet. Broilers fed 0 and $45 \%$ CBP-mix diets had significantly (P < 0.05 ) higher back weights than broilers fed $15 \%$ CBP-mix diet. For wing weights, 0 and $45 \%$ CBP-diets were significantly $(\mathrm{P}<0.05)$ heavier than the birds fed 30\% CBP-mix diet. Broilers fed 0\% CBP-mix had significantly $(\mathrm{P}<0.05)$ smaller breast and liver weights compared to birds on other dietary treatments. Comparable thigh weights were recorded in birds on $0 \%$ and $45 \%$ CBP-mix diet but were significantly ( $\mathrm{P}$ $<0.05$ ) higher than birds on 15 and 30\% CBP-mix diets. Heart weight of birds fed $45 \%$ CBP-mix were significantly $(\mathrm{P}<0.05)$ heavier than those on other diets with birds on 30\% CBP-mix having the lowest heart weight. Liver weight followed the same trend as breast weight. For gizzard, the highest value was recorded by birds on 15\% CBP-mix diet which was significantly $(\mathrm{P}<0.05)$ higher than birds fed $30 \%$ CBP-mix.

Table 2: Carcass Characteristics of Broilers fed varying levels of CBP-mix and control

\begin{tabular}{cccccc}
\hline & \multicolumn{5}{c}{ Graded levels of CBP-mix } \\
Parameters & $0 \%$ & $15 \%$ & $30 \%$ & $45 \%$ & LOS \\
\hline Final Live Weight $(\mathrm{Kg})$ & $2.62 \pm 0.25^{\mathrm{a}}$ & $2.19 \pm 0.22^{\mathrm{b}}$ & $2.25 \pm 0.22^{\mathrm{b}}$ & $2.06 \pm 0.11^{\mathrm{b}}$ & $*$ \\
Carcass Weight $(\mathrm{Kg})$ & $1.97 \pm 0.03^{\mathrm{a}}$ & $1.62 \pm 0.17^{\mathrm{b}}$ & $1.70 \pm 0.18^{\mathrm{ab}}$ & $1.48 \pm 0.03^{\mathrm{b}}$ & $*$ \\
Dressing Percentage $(\%)$ & $75.10 \pm 0.46^{\mathrm{ac}}$ & $73.80 \pm 1.37^{\mathrm{bc}}$ & $75.83 \pm 0.85^{\mathrm{a}}$ & $71.67 \pm 2.27^{\mathrm{b}}$ & $*$ \\
Neck Weight $(\mathrm{g} / \mathrm{Kg})$ & $50.37 \pm 3.11^{\mathrm{ab}}$ & $52.30 \pm 6.76^{\mathrm{a}}$ & $51.83 \pm 2.81^{\mathrm{a}}$ & $47.80 \pm 1.01^{\mathrm{b}}$ & $*$ \\
Back Weight $(\mathrm{g} / \mathrm{Kg})$ & $158.33 \pm 9.05^{\mathrm{a}}$ & $135.00 \pm 2.93^{\mathrm{b}}$ & $146.97 \pm 1.27^{\mathrm{ab}}$ & $154.97 \pm 3.42^{\mathrm{a}}$ & $*$ \\
Wings $(\mathrm{g} / \mathrm{Kg})$ & $71.03 \pm 3.75^{\mathrm{a}}$ & $71.00 \pm 1.18^{\mathrm{ab}}$ & $70.20 \pm 5.00^{\mathrm{b}}$ & $72.30 \pm 9.82^{\mathrm{a}}$ & $*$ \\
Breast $(\mathrm{g} / \mathrm{Kg})$ & $120.53 \pm 5.19^{\mathrm{b}}$ & $157.67 \pm 1.86^{\mathrm{a}}$ & $170.73 \pm 8.81^{\mathrm{a}}$ & $160.87 \pm 1.40^{\mathrm{a}}$ & $*$ \\
Thigh $(\mathrm{g} / \mathrm{Kg})$ & $118.90 \pm 3.60^{\mathrm{a}}$ & $104.53 \pm 8.02^{\mathrm{b}}$ & $109.10 \pm 4.69^{\mathrm{b}}$ & $110.20 \pm 1.20^{\mathrm{ab}}$ & $*$ \\
Drumstick $(\mathrm{g} / \mathrm{Kg})$ & $98.50 \pm 4.42$ & $99.20 \pm 10.81$ & $107.75 \pm 27.33$ & $88.43 \pm 2.36$ & NS \\
Heart $(\mathrm{g} / \mathrm{Kg})$ & $4.30 \pm 0.52^{\mathrm{b}}$ & $5.40 \pm 0.46^{\mathrm{bc}}$ & $5.90 \pm 1.05^{\mathrm{c}}$ & $6.13 \pm 0.13^{\mathrm{a}}$ & $*$ \\
Liver $(\mathrm{g} / \mathrm{Kg})$ & $20.67 \pm 0.81^{\mathrm{b}}$ & $27.60 \pm 4.07^{\mathrm{a}}$ & $30.10 \pm 3.16^{\mathrm{a}}$ & $29.83 \pm 6.11^{\mathrm{a}}$ & $*$ \\
Gizzard $(\mathrm{g} / \mathrm{Kg})$ & $41.53 \pm 7.99^{\mathrm{ac}}$ & $42.30 \pm 9.64^{\mathrm{a}}$ & $38.10 \pm 3.16^{\mathrm{b}}$ & $39.33 \pm 8.36^{\mathrm{bc}}$ & $*$ \\
\hline
\end{tabular}

$a b c=$ means with difference superscript on the same row differ significantly $(\mathrm{p}<0.05)$; NS=not significant $(\mathrm{p}>0.05)$; CBP-

mix=Cassava tuber meal, Burukutu waste and Palm oil mixture; LOS=level of significant; $*=\operatorname{significant~at~}(\mathrm{p}<0.05)$

\subsection{Serum Biochemistry of broilers fed varying levels of CBP-mix and Control Diet}

Table 3 shows that Albumin level is lowest in diet 1 with a value of 8.33 and highest in diet 4 with a value of 11.00. Alkaline phosphatase and total protein increased as the level of CBP-mix inclusion increased, ranging from 13.33 in diet 1 to 21.00 in diet 4 and 36.00 to 46.00 respectively. On the contrary, creatinine values decreased as the dietary inclusion levels of CBP-mix increased from 21.00 in diet 1 to 14.33 in diet 4 . Diet 3 however had the highest globulin level of 34.33 while diet 1 had the lowest globulin level of 26.67 . 
Table 3: Serum Biochemistry of broilers fed varying levels of CBP-mix

\begin{tabular}{|c|c|c|c|c|c|}
\hline \multirow[b]{2}{*}{ Parameters } & \multicolumn{4}{|c|}{ Graded levels of CBP-mix } & \multirow[b]{2}{*}{ LOS } \\
\hline & $0 \%$ & $15 \%$ & $30 \%$ & $45 \%$ & \\
\hline Albumin (mmol/l) & $8.33 \pm 1.53^{\mathrm{b}}$ & $10.67 \pm 1.15^{\mathrm{a}}$ & $10.33 \pm 3.79^{\mathrm{a}}$ & $11.00 \pm 1.00^{\mathrm{a}}$ & $*$ \\
\hline Globulin (mmol/l) & $26.67 \pm 5.13^{b}$ & $31.33 \pm 2.52^{\mathrm{ab}}$ & $34.33 \pm 3.06^{\mathrm{a}}$ & $28.00 \pm 6.56^{\mathrm{b}}$ & $*$ \\
\hline Total Protein (mmol/l) & $36.00 \pm 4.00^{\mathrm{b}}$ & $42.00 \pm 3.61^{\mathrm{ab}}$ & $44.67 \pm 2.89^{\mathrm{a}}$ & $46.00 \pm 1.00^{\mathrm{a}}$ & $*$ \\
\hline Alkaline Phosphatse (i.u/l) & $13.33 \pm 0.58^{b}$ & $16.67 \pm 2.89^{\mathrm{ab}}$ & $18.67 \pm 2.08^{\mathrm{a}}$ & $21.00 \pm 2.65^{\mathrm{a}}$ & $*$ \\
\hline Creatinine (mmol/l) & $21.00 \pm 1.73^{\mathrm{a}}$ & $18.33 \pm 3.06^{\mathrm{ac}}$ & $16.67 \pm 2.08^{\mathrm{bc}}$ & $14.33 \pm 0.58^{\mathrm{b}}$ & $*$ \\
\hline
\end{tabular}

$\mathrm{ab}=$ Means with difference superscript on the same row differ significantly $(\mathrm{P}<0.05)$; $\mathrm{CBP}$-mix=Cassava tuber meal; burukutu waste and palm oil mixture; LOS $=$ Level of significant; * = Significant at $(\mathrm{P}<0.05)$

\section{Discussion}

\subsection{Carcass Characteristics of Broilers Fed The Experimental Diets.}

Observed significant differences in the final weight of the broilers showed broilers fed $45 \%$ CBP-mix having smaller weight than those on diets containing $0 \%, 15 \%$, and 30\% CBP-mix diets. This was because birds on this diet (45\% CBP-mix) consumed less of the feed which might be due to its relatively dusty nature. Therefore, CBP-mix ratio other than the one used in this study could be used to reduce dustiness of the feed. The dressing percentage value of 71.67 to $75.83 \%$ obtained differed from 69.16 to $70.20 \%$ reported by Chukwuka et al. (2010) who also fed CBP-mix. The differences in dressing percentage could be due to differences in experimental set up such as location, composition of CBP-mix, composition of experimental diet etc.

The result obtained for breast weight in this study is in line with those of Okorie et al. (2010) who observed an increase in breast weight with an increase in inclusion level of brewers dried grains. Furthermore, Morrissey et al. (1998) stated that the carcass fatness could be affected especially when dietary energy level is changed. The higher breast weight with increasing CBP-mix in diet may be an indication of better conversion of dietary nutrients into meat. This also may be a pointer to the fact that with reduction in dustiness, CBP-mix will be a good substitute for maize as dressing percentage showed the relative efficiency of the diet in reducing the proportion of non-edible to edible parts.

Increasing trend in heart weight, due to increasing level of CBP-mix from diet 1 to diet 4 may be as the result of the increasing demand on the heart to pump more oxygenated blood to help with the detoxification of the effect of CBP-mix. Similar result was obtained by Adeyemo and Longe (2007) who observed an enlargement in the heart of broiler chicken fed varying levels of cotton seed cake.

\subsection{Serum Biochemistry of Broiler Fed Experimental Diets}

Observed differences in albumin levels across the treatments were normal and within the ranges of $12.5 \mathrm{mmol} / 1$ to $22 \mathrm{mmol} / 1$ reported by Akinmutimi and Onen, (2008). This indicates that substitution of maize with CBP-mix did not adversely affect the nutritive quality of the diets especially with respect to serum protein.

Alkaline phosphatase tend to increase when bile flow in the liver is decreased therefore diet 1 had the highest capacity for fat digestion followed by diets 2, 3 and 4 respectively. The result indicated that as the level of CBP-mix increased in the dietary treatments, the alkaline phosphatase of birds also increased.

Creatinine, an indicator of the extent of muscle wastage also indicates decreased kidney function. Ologhobo et al. (1993) reported that the high level of creatinine are sometimes seen in the kidney diseases due to the kidney's job of excreting creatinine, muscle, degeneration and exposure to toxic compounds which impair kidney function. Unlike all other parameters discussed creatinine was the highest in control diet that in dietary treatments 2, 3, and 4. Obtained result showed that with increasing level of CBP-mix inclusion creatinine value of the blood decreases, this is similar to the outcome reported by Abu, (2010) which showed the effect of Bambara groundnut milling waste based diets on serum biochemical constituents of broiler chicks.

Total proteins are the most abundant compound in serum. The protein make up of an animal is of important diagnostic significance because they are involved in enzyme, hormones and antibodies synthesis and as a reserve source of nutrition for the body tissues and muscle. It appears therefore that diet 4 with the highest level of inclusion of CBP-mix had a better protein quality than those with decreasing levels of CBP-mix. However, total protein values are within the reference range of $32.5 \mathrm{mmol} / 1$ to $76.1 \mathrm{mmol} / 1$ reported by Rajurker, (2009). This is an indication that the quality of protein in the experimental diet was adequate (Iyayi and Tewe, 1998) and the consumption by birds did not result in stress, disease and starvation or malnutrition. McDonald, (1996) reported that low total protein could reflect stress, chronic disease, parasitism, starvation or malnutrition while elevated values may induce dehydration, chronic infection or leukemia.

Though serum globulin differed among dietary treatments, they were however at the normal globulin levels and within the reference range $21.3 \mathrm{mmol} / 1$ to $30.2 \mathrm{mmol} / 1$ reported by Adeyemo, (2008). This is an 
indication that the birds were not under stress of disease; parasite or anaemia. Harris (2000) observed that globulin levels may be elevated as a result of parasites, viral or bacterial infection and kidney dysfunction among others. Conversely, it may be depressed due to nephrosis, and acute haemolytic anaemia. The changes in the serum biochemical constituent can be ascribed to enhanced digestion, absorption, and utilization of the CPBmix.

\section{Conclusion}

The result of this study shows that 30\% CBP-mix can be incorporated to the starter and finisher diets of broilers without adverse effect on the carcass characteristics and serum biochemical profile of the birds.

\section{Recommendations}

- Research effort should be directed towards higher inclusion level of CPB-mix in broilers diet.

- Palm oil in CPB-mix should be included at higher ratios to further reduce its dustiness and improve intake.

\section{References}

[1]. H.T. Abu, Effect of enzyme supplementation of bambara groundnut milling waste based diet on growth performance, haematological and serum biochemical constituent of broilers chicks, bachelor thesis, Department of Animal Production, Kogi State University, Anyigba, Nigeria,

[2]. G.O. Adeyemo, Effects of cottonseed cake based diets on haematological and serum biochemistry of egg type chickens, International Journal of Poultry Science, 7(1), 2008, 23-27.

[3]. G.O. Adeyemo and O.G. Longe, Effects of graded levels of cotton seed cake on performance, Haematological, and carcass characteristics of broilers fed from fry old to 8 weeks of age, African Journal of Biotechnology, 6(8): 2007, $1064-1071$.

[4]. A.H. Akinmutimi and G.E. Onen, The response of broilers finisher birds fed graded levels of yam peel meal in place of maizebased diets, International Journal of Poultry Science, 7(5), 2008, 474-479.

[5]. AOAC, Association of Official Analytical Chemist, Official method of analysis, $16^{\text {th }}$ edition Washington DC, 1995.

[6]. O.K. Chukwuka, A.B.I. Udedibie, N.J. Okeudo, N.O. Aladi, B.O. Esonu, O.O.M. Iheshiulor and A.A. Omede, Performance and Haematological Parameters of Broilers Fed Graded Levels of a Mixture of Sun-Dried Cassava Tuber Meal, Brewers' Dried Grain and Palm Oil as a Substitute for Maize, Report and Opinion, 2, 2010, 104-110.

[7]. B.O. Esonu, Animal nutrition and feeding: A functional Approach (Memory press, Owerri, Nigeria, 2000$)$ 198-204.

[8]. D.J. Harris, Clinical tests. in: T.N. Tully, M.P. Lawton, G.M. Dorrestein, (Ed), Avian medicine (Butterworth Heinemann, Oxford, 2000).

[9]. O.O. Ifatimehin, S.D. Musa and J.O. Adeyemi, An analysis of the changing land use and its impact on the environment of Anyigba town, Nigeria, Journal of Sustainable Development in Africa, 10, 2006, 4-8.

[10]. E.A. Iyayi, O.O. and Tewe, Serum total protein, Urea, and creatinine levels as indices of quality of cassava diets for pigs, Trop. Vet., 36, 1998, 59-67.

[11]. K. Kleczek, E. Wilkiewicz-Wawro, K. Wawro and W. Makowski, Effect of body weights of day-old Muscovy ducklings on growths and carcass traits. Arch. Tierz, 50(2), 2007, 204-213.

[12]. P. McDonald, R.A. Edward and J.F.D. Green-Halgh, Annual Nutrition 5 (Addison Wesley Longman ltd, Edinburgh, U.K., 1991) 606.

[13]. P.A. Morrissey, P.J.A. Sheehy, K. Galvin, J.P. Kerry, D.J. Buckley, Lipid stability in meat and meat products, Meat science, 49, 1998, 573-586.

[14]. K.C. Okorie, Evaluation of Jacaranda mimosifolia (T) stans leaf meal as ingredients in finisher broilers diet: performance, carcass and organ weight characteristics. Anim. Prod. Res. Adv. 2(1), 2006, $44-49$.

[15]. K.C. Okorie, O. Gabriel, F.N. Ehirim, R.C. Okorie, J.N. Ikpe, C.T. Muoneme, C. Okoro-Ugo and C. Nwosu, Effect of Synthetic Enzyme Fortified Brewers Dried Grain as Feed Source on Broilers Finisher; Performance, Haematology and Biochemical Profiles. Global Research Journal of Science, 1, 2011, 123- 31

[16]. A.D. Ologbodo, D.F. Apata, T. Oloyede and R.O. Akinpelu, A comparison of protein fractions prepared from luna beans (phoseolus lunatus) in starter diets for broiler chicks, J. Appl. Anim. Res 4:1993, 13-30.

[17]. J.I. Rajurker, Total protein rangers ranges of animal, International Journal of Poultry Science 7(1):2009, $23-27$.

[18]. S. Reitman, and S. Frankel, A colorimetric method for the determination of serum glutamic oxaloacetic and glutamic pyruvic transaminases, American Journal of Clinical Pathology, 28; 1957, 56-63.

[19]. G.O. Tona, J.A. Akinlade, R.O. Olabanji and A.B. Adekitan, Performances and nutrient digestibility of weaned rabbits fed graded levels of piliostigma thonningii leaf meal-based diets, Proceeding of 35th Conference of Nigerian Society for Animal production, 2010, 278-281.

[20]. A.B.I. Udedibie, O.J. Chukwurah, G.E. Enyenihi, H.O. Obikaonu and I.C. Okoli, The use of sun-dried cassava tuber meal, Brewers' dried grains and palm oil to simulate maize in the diet of laying hens. Journal of Agricultural Technology, 8, 2012, $1269-1276$. 